\title{
Helgoland Roads, North Sea: 45 Years of Change
}

\author{
Karen Helen Wiltshire • Alexandra Kraberg • Inka Bartsch • Maarten Boersma • \\ Heinz-Dieter Franke • Jan Freund • Christina Gebühr • Gunnar Gerdts • \\ Karina Stockmann • Antje Wichels
}

Received: 7 October 2008 /Revised: 14 September 2009 / Accepted: 27 September 2009

(C) Coastal and Estuarine Research Federation 2009

\begin{abstract}
The Helgoland Roads time series is one of the richest temporal marine data sets available. Running since 1962, it documents changes for phytoplankton, salinity, Secchi disc depths and macronutrients. Uniquely, the data have been carefully quality controlled and linked to relevant meta-data, and the pelagic time series is further augmented by zooplankton, intertidal macroalgae, macrozoobenthos and bacterioplankton data. Data analyses have shown changes in hydrography and biota around Helgoland. In the late 1970s, water inflows from the south-west to the German Bight increased with a corresponding increase in flushing rates. Salinity and annual mean temperature have also increased since 1962 and the latter by an average of
\end{abstract}

K. H. Wiltshire $\cdot$ A. Kraberg $\cdot$ M. Boersma $\cdot$ H.-D. Franke $\cdot$

C. Gebühr $\cdot$ G. Gerdts $\cdot$ A. Wichels

Biologische Anstalt Helgoland, Alfred Wegener Institute for Polar and Marine Research,

P.O. Box 180, 27483 Helgoland, Germany

K. H. Wiltshire $(\bowtie)$

School of Engineering and Science, Jacobs University Bremen,

Campus Ring 1,

28759 Bremen, Germany

e-mail: Karen.Wiltshire@awi.de

I. Bartsch

Alfred Wegener Institute for Polar and Marine Research, P.O. Box 1201 61, 27515 Bremerhaven, Germany

J. Freund

ICBM, University of Oldenburg,

P.O. Box 2503, 26111 Oldenburg, Germany

\section{K. Stockmann}

Institute for Coastal Research, GKSS Research Centre,

Max-Planck-Straße 1,

21502 Geesthacht, Germany $1.67^{\circ} \mathrm{C}$. This has influenced seasonal phytoplankton growth causing significant shifts in diatom densities and the numbers of large diatoms (e. g. Coscinodiscus wailesii). Changes in zooplankton diversity have included the appearance of the ctenophore Mnemiopsis leidyi. The macroalgal community also showed an increase in green algal and a decrease in brown algal species after 1959. Over 30 benthic macrofaunal species have been newly recorded at Helgoland over the last 20 years, with a distinct shift towards southern species. These detailed data provide the basis for long-term analyses of changes on many trophic levels at Helgoland Roads.

Keywords Plankton - Macrobenthos · Bacteria - Nutrients . North Sea $\cdot$ Climate change

\section{Introduction}

Time series in marine systems are becoming more important due to the evidence of rapid changes in climate (IPCC 2001a, b; IPCC 2007). In marine systems, data sets monitoring biological species are rarely both highly temporally resolved as well as truly long term. This is mostly due to the immense effort required to keep them going. In the open ocean, this can be particularly difficult in bad weather since it is also almost impossible to reach sites or remain on station (such as the BATS Time Series http:// bats.bios.edu/index.html) for longer time periods. Many offshore data sets exist which involve monthly sampling, and the maximum resolution achieved in inshore sites is often weekly sampling. Many modern systems involving buoys, floats and even shipboard automatic samplers (e.g. FERRYBOXES; Petersen et al. 2008) have been deployed in the past 10 years to address these difficulties, but most of these time series are still relatively short. 
Although time series sites include Arctic, boreal, temperate, Mediterranean and tropical climates, there are only a few time series which cover large areas. Examples include the American Atlantic coasts (http://stellwagen.er. usgs.gov/) and the unique Continuous Plankton Recorder data sets which cover the Atlantic and North Sea since the 1800s (Reid et al. 1998; Reid et al. 2001). Few pelagic data sets have a daily resolution, and even then, they do not include organisms identified to species and measurements of physico-chemical parameters simultaneously.

In this regard, the Helgoland Roads time series is unique and one of the richest temporal marine data sets available. The series is based on daily (five times a week) surface water sampling since 1962 until the present, resulting in a pelagic data set comprising phytoplankton, temperature, salinity, Secchi depth and nutrients. Concurrently, zooplankton, chlorophyll and light penetration depths are sampled biweekly, and rocky shore macroalgae, macrozoobenthos and pelagic bacteria are now sampled on a regular basis (Franke et al. 1999; Gutow et al. 2007; Gerdts et al. 2004; Bartsch et al. 2004; Reichert et al. 2008). Thus, the Helgoland Roads pelagic time series is supported by additional data.

In this paper, changes over the last 45 years in the German Bight based on data at Helgoland Roads are presented and discussed. We are particularly aware of how difficult this is in the North Sea, which in the last 100 years has experienced repeated overfishing, large-scale dredging, coastal defence and dyke construction, increased and decreased pollutant loading as well as warming. Here, we show examples of changes based on the temporally highly resolved pelagic and benthic data sets at Helgoland Roads.

\section{Data Sets and Methods}

\section{Pelagic Data}

Since 1962, surface water samples have been taken (usually before 9 A.M.) on working days at the "Kabeltonne" site (54 $\left.11.3^{\prime} \mathrm{N}, 7^{\circ} 54.0^{\prime} \mathrm{E}\right)$ between the two islands at Helgoland using a bucket. The surface water samples are representative of the entire water column which is always well mixed as a result of strong tidal currents (Hickel 1972). The depth at this site fluctuates between 6 and $10 \mathrm{~m}$ over the tidal cycle. Secchi depth is measured from the vessel on station, and the water temperature was measured immediately. The bucket sample is mixed and sub-sampled into a glass bottle for future analyses of nutrients, salinity and phytoplankton.

The pelagic time series of Helgoland Roads (with the exception of zooplankton data which are currently being revised) have been successfully entered into an open-access data bank (www.pangaea.de) and cross-checked with other data sets from the same water bodies and reference data sets for the North Sea (Wiltshire and Dürselen 2004; Raabe and Wiltshire 2008). Therefore, the pelagic data sets are now sufficiently understood with problems, errors and corrections documented. Thus, they can be used confidently as reference data to assess long-term changes to the North Sea pelagic ecosystem. The primary sampling at Helgoland Roads continues to be conducted as it has been since its initiation in 1962, and in addition, a highly resolved automated monitoring system (FERRYBOX; Petersen et al. 2008) was installed to understand the temporal variation in temperature, salinity, nutrients and fluorescence on an hourly basis.

\section{Nutrients and Salinity}

The nutrients (phosphate, ammonium, nitrate and nitrite) are measured immediately on a filtered subsample from the daily Helgoland Roads surface water sample using the standard colorimetric methods as described by Grasshoff (1976). This subsample is also used to measure the salinity with a salinometer (Autosal, Gamma Analysen Technik $\mathrm{GmbH}$ ). The 45 years of nutrient and salinity data have been reviewed and quality controlled by Raabe and Wiltshire (2008).

\section{Phytoplankton}

The phytoplankton sub-sampled from the Helgoland Roads sample is preserved in a brown glass bottle using Lugols' solution (final concentration, $0.1 \%$ Lugol). The daily phytoplankton counting is conducted after Lund et al. (1958) in 25 or $50 \mathrm{ml}$ Utermöhl settling chambers using an inverted microscope (Zeiss Axiovert 135) to the species level when possible or otherwise differentiated into defined size classes (Hoppenrath et al. 2007). The species lists and quality control used were described in Wiltshire and Dürselen (2004). Permanent slides are prepared approximately every month and when a new species is identified.

Over 360 phytoplankton species are listed for Helgoland, and thus, this is part of the routine microscopic monitoring of microalgae (Hoppenrath 2004). This species list is updated regularly and taxonomic images stored in an open-access taxonomic database Plankton* Net (http://. planktonnet.awi.de) (see below).The most reliable algal counts over the complete time period are for diatoms. The accuracy of the total counts of flagellates is more reliable in recent years due to increased microscopical size resolution (Wiltshire and Dürselen 2004).

\section{Zooplankton}

The Helgoland Roads time series of meso- and macrozooplankton was initiated by Greve in 1974 (Greve et al. 
2004). The initial aim of this time series was to provide the data necessary for simulation models on trophodynamic interactions in the pelagic zone. Since then, two nets have been deployed three times a week with different mesh sizes: a $150-\mu \mathrm{m}$ Nansen net (aperture $17 \mathrm{~cm}$, net length $100 \mathrm{~cm}$ ) and a $500-\mu \mathrm{m}$ CalCOFI net (aperture $100 \mathrm{~cm}$, net length $400 \mathrm{~cm}$ ). Oblique hauls are made with a Nansen net, whereas the CalCOFI net is towed behind the research vessel. Prior to 1981, live samples were counted, but from 1982, samples have been preserved in $4 \%$ formaldehyde and stored cool and dark until analysed. As a consequence, delicate species such as ctenophores and hydromedusae may be underestimated from 1982 onwards, and this is considered to be the likely cause of the relatively late discovery of the invasion of the ctenophore Mnemiopsis leidyi (Boersma et al. 2007). For more detail on the sampling procedure as well as a full list of counted taxonomic and ontogenetic entities, see Greve et al. (2004).

\section{Bacteria and Viruses}

The microbiological efforts at Helgoland Roads that were initiated in the 1960s reflect the "Zeitgeist"/paradigms of the scientific community at the time. Thus, one of the longest data sets is that of colony-forming bacterial units (CFU) from 1962 to 2000 (weekly) which has been quality controlled and is recognised as highly "biased". Besides "abundance data" (CFU and total bacterial counts), a number of activity parameters (ATP, Exo-enzymes) were measured irregularly over the years (Gerdts et al. 2004). Environmental microbiology underwent a paradigm shift in the 1980s with the discovery of the "great plate count anomaly" (Staley and Konopka 1985) which highlighted the discrepancy between the numbers of culturable bacteria and those which were counted by epifluorescent microscopy. Since the introduction of molecular techniques, this was found to be even more pronounced. We now know that the "great plate count anomaly" was a quantitative and qualitative misinterpretation of the bacterial community. Most of the colony-forming units (i.e. the culturable bacteria) can be affiliated to 'lab weeds', and the active majority escaped detection for decades. In 1996, we introduced new genetic techniques to the analysis of Helgoland Roads samples. Now, denaturing gradient gel electrophoresis (DGGE) and the ribosomal intergenic spacer analysis (RISA) enable the determination of the diversity and identity of bacteria without culturing bias.

Helgoland Roads is one of the few sites in the world where bacteriophages are regularly counted using electron microscopy and genetic techniques. Viruses (virus-like particles, VLPs) were counted by epifluorescence microscopy after staining with the DNA dye Yo-Pro (SIGMA) on $0.02 \mu \mathrm{m}$ polycarbonate filters. The morphology of a subset of isolated bacteriophages (viruses infecting bacteria) was determined by electron microscopy. The genetic relatedness of these bacteriophages within the different viral groups was described using bromodesoxyuridin-labelled DNA probes by whole DNA-DNA hybridisation experiments (see also Wichels et al. 1998). The introduction of new techniques and cooperation with the Max Planck Institute for Marine Microbiology now makes Helgoland Roads one of the best microbially analysed sites worldwide (Sapp et al. 2007; Eilers et al. 2001; Pernthaler and Pernthaler 2005; Alonso and Pernthaler 2006; Beardsley et al. 2003).

\section{Benthic Data}

A very old benthic time series dating back to the midnineteenth century is available for macroalgae and zoobenthos for the rocky intertidal, and it further supports the long-term monitoring at Helgoland.

\section{Benthic Flora}

Although the historical information on macroalgae is mostly qualitative and thus subjective (for references, see Bartsch and Kuhlenkamp 2000), an extensive local herbarium exists, which dates back to 1846 providing approximately 8,000 records of macroalgae. This is a unique historical data set for the southern North Sea. Online information is available at http://data.gbif.org/datasets/ provider/17. Reliable and consistent intertidal and subtidal sampling programmes associated with extensive mapping have been introduced both for flora and fauna in 2003 (Bartsch et al. 2004; Reichert et al. 2008). A stationary grid of 140 geo-referenced sampling points was established in 2004 in the eulittoral zone of Helgoland using $50 \times 50 \mathrm{~cm}$ quadrats in order to quantify the percent cover of all macroalgal species. Samples were taken for the first time in autumn 2003 and from 2005 onwards every winter and summer. For 2006, spring and autumn data are also available (Bartsch and Kuhlenkamp, unpublished data). In the subtidal, three parallel permanent geo-referenced diving transects were established in 2008. Percent cover and local frequency of all visible macroalgae are quantified once a year during summer at $0.5-\mathrm{m}$ intervals between 4 and $12 \mathrm{~m}$ depths below mean low water spring level. All data are visualised via a geographic information system enabling rapid spatial analysis of abundance and the spread or retreat of species. Both surveillance sites are part of a monitoring initiative for the water frame work directive and have been established in cooperation with the State Agency for Nature and Environment Schleswig-Holstein, Germany. Additionally, intertidal biotopes have been described (Bartsch and Tittley 2004), and the change in their spatial extent is followed via conventional mapping and hyperspectral 
remote sensing (Thiemann and Bartsch 2005; Hennig et al. 2007). Mapping of the subtidal kelp forest is under way (Hass and Bartsch 2008).

\section{Benthic Fauna}

The species lists of benthic fauna at Helgoland include over 650 species. The monitoring authorities have taken over a large proportion of the difficult sublittoral monitoring (Boos et al. 2004) which should ensure continuation of the programme in the future. In the meantime, because of the need to react to special situations such as new species entering the system (both as introduced neobiota and as immigrants), specialised sampling is carried out for several isopods and amphipods (Franke and Gutow 2004) and, in the pelagic, the ctenophore Mnemiopsis (Boersma et al. 2007). An additional programme that monitors the organisms colonising the buoys around Helgoland was introduced in 2002. Regularly disturbed communities such as the fouling communities on buoys and pontoons are often used as stepping stones by newcomers. Monitoring of these communities allows the early recognition of species which could successfully settle in the natural communities. Recently, sampling for macrofauna in the intertidal has been reactivated (Reichert and Buchholz 2006).

\section{Hydrographic Models}

The hydrography in the German Bight is perhaps the most important information to help understand the variation in the data recorded at Helgoland. Currents carry neobiota through the system. Larval dispersion is dependent on water movement, and the patchiness of algal blooms is also governed by it. Thus, hydrographic modelling was carried out. Reconstructed fields of sea surface height and barotropic currents for the period 1958-2002 with high resolution in space and time were taken from the coastDat data base (www.coastdat.de). The reconstruction covers the whole North Sea, whereas the spatial resolution of the triangular grid in the area of interest (German Bight) varies from $100 \mathrm{~m}$ around Helgoland to kilometres offshore (Plüß 2004). The hydrodynamic data in coastDat were generated by the Federal Waterways Engineering and Research Institute (Bundesanstalt für Wasserbau, BAW) during the EU funded project Hindcast of Dynamic Processes of the Ocean and Coastal Areas of Europe using the twodimensional finite element model TELEMAC-2D (Hervouet and van Haren 1996). The hydrodynamic model was driven by atmospheric wind and pressure fields with a spatial resolution of $50 \mathrm{~km}$ and a temporal resolution of $1 \mathrm{~h}$ (Feser et al. 2001), which were produced by down-scaling National Centers for Environmental Prediction re-analyses (Kistler et al. 2001). Residual flow anomalies from the period 1958-2000 (where time coefficients are the principal components) were used for an empirical orthogonal function (EOF) analysis to derive characteristic patterns of transport variability in the German Bight.

\section{Data Analyses and Statistics}

Wiltshire and Manly (2004) carried out an in-depth analysis of the changes in temperature during 1962-2002. They analysed the temperature data, allowing for a multitude of different trends (ranging from linear to quintic polynomial fits) and observed that the most parsimonious fit was a linear one. Increasing the order of the fit did not significantly increase the predictive power of the model. The same method was applied here, and the resulting linear trend was highly significant $(p<0.001)$. The estimated temperature increase is $0.037^{\circ} \mathrm{C}$ per year. This corresponds to an increase of $1.67^{\circ} \mathrm{C}$ for the 45 years since 1962 .

The statistics used for the investigation of potential causes of the change in the timing of the phytoplankton spring bloom were described in detail in Wiltshire et al. (2008). A stepwise forward multiple regression analysis was used and the mean diatom day (MDD) compared with copepod densities, temperature, salinity, Secchi depths, total dissolved inorganic nitrogen, phosphate, sunshine hours as well as wind for the first quarter of the year. For each MDD, we first calculated the mean of the measurements made prior to the MDD under investigation for all years. Second, we subtracted the grand mean of the 30 years from the mean of the year under investigation. Lastly, we normalised the deviation of the year under investigation from the grand mean by dividing it by the standard deviation of the grand mean. This procedure was repeated for all years, resulting in 30 sets of nutrient concentration anomalies, copepod densities and abiotic parameters. This data set was used for the multiple linear regression analysis.

In this paper, an empirical orthogonal function analysis of the residual flow was executed to derive the maps of dominant transport patterns in the German Bight. These patterns show water transport anomalies-residual transports, which exclude mean transport, tidal transport and seasonal fluctuation. The amplitudes of these anomalies at each time step are characterised by the principal components (PCs) of each pattern. EOF analysis is a principal component analysis (PCA) which determines a set of orthogonal functions that characterises the covariability of the time series for a set of grid points in a simple manner.

It is an orthogonal linear transformation that transforms the data to a new coordinate system. The result is a coordinate system whereby the greatest variability of data can be explained by the first coordinate (the first principal component) alone. The second greatest variability can be explained by the second coordinate and so on. 


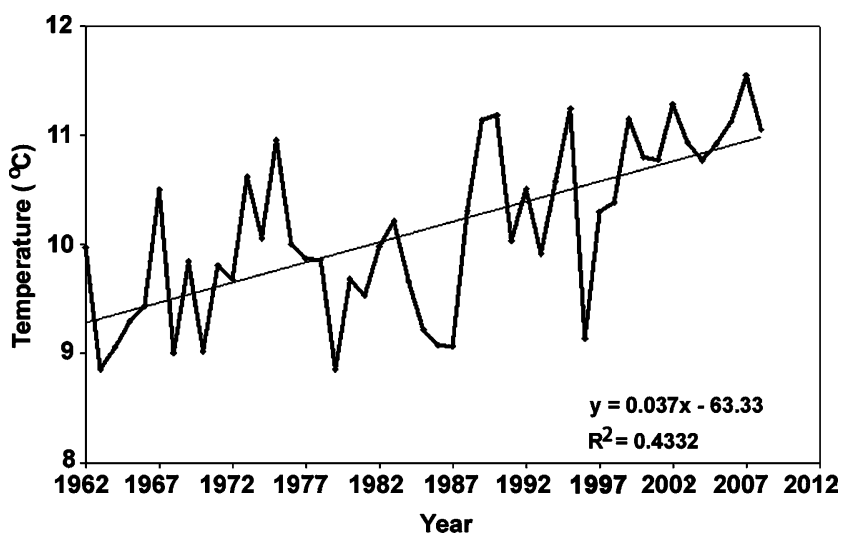

Fig. 1 Mean yearly trend of temperature in surface water at Helgoland Roads $(p<0.001)$

Normally, PCA analysis is used to develop linear interdependencies between the time series of numerous parameters. In the case of an EOF analysis, the time series of only one parameter but on different spatial points in a map are taken to derive maps of dominant patterns of variability. A complete description of the EOF analysis can be found in von Storch and Zwiers (1999).

\section{Data Archives}

Perhaps one of the most time-consuming aspects of longterm monitoring is adequate and accurate data archiving. As the length of a data series increases, the proper electronic archiving becomes of paramount importance. Over the years, techniques and personnel change, and it is vital that these do not affect the continuity of the data and their comparability with other data sets. Therefore, the raw data and also the accompanying meta-data such as sampling methodologies and protocols need to be archived. At the Alfred Wegener Institute, this task is achieved using the online database Pangaea (http://www.pangaea.de), which is a global environmental data archive hosting data from a multitude of research projects and individual data providers from all over the world. Data are archived in a standardised manner and are assigned a digital object identifier ensuring that data are available and retrievable on the long term.

A database has also now been established to deal specifically with taxonomic data for plankton. PLANKTON*NET (http://planktonnet.awi.de) is a collaborative database project, and like Pangaea, it receives contributions from data providers from all over the world (both current observations and historic data). PLANKTON*NET currently contains images, references and taxonomic descriptions for about 3000 plankton species and is also used to regularly archive images to illustrate the taxonomic longterm data from Helgoland. Through these images in PLANKTON*NET, it has been possible to create a taxonomic baseline for the Helgoland Roads data sets in Pangaea, allowing external checks of the taxonomic identifications forming the basis of the Helgoland Roads data series.

\section{Results and Discussion}

Changes Observed at Helgoland

At the beginning of the previous century, it was realised at Helgoland that rapid change, mostly anthropogenically induced, could affect marine systems. In order to assess changes, such as the effects of increased pollutants and nutrients, monitoring programmes were set up. Since then, however, the questions to which they were applied have changed and grown. At Helgoland Roads, overfishing, new species/aliens, climate change and particularly changes in the hydrography are included in evaluations.

The identification of shifts and trends in long-term data is not trivial. For example, some clear linear trends in temperature have been observed. However, the situation is more complex when considering ecosystem shifts (Freund et al. 2006; Wiltshire et al. 2008). Here, we describe our understanding of the main changes observed to date.

Changes in the Physical Environment

\section{Temperature}

The long-term temperature trend was evaluated. The annual mean temperature in the surface water at Helgoland Roads has risen significantly by a mean value of $1.67^{\circ} \mathrm{C}$ since 1962 (see also Wiltshire et al. 2008) (Fig. 1). Both the summer and winter months have become significantly warmer. The trend is to higher temperatures both in summer and winter, whereby the actual curve mode (seasonality curve) has changed little since 1962. The number of days

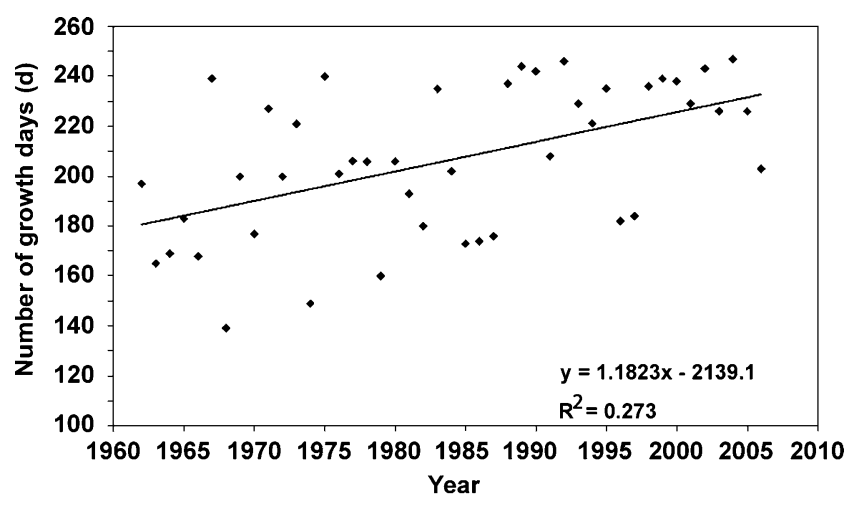

Fig. 2 Shift in number of "growth" days, i.e. days with temperatures over $5^{\circ} \mathrm{C}(p<0.001)$ 


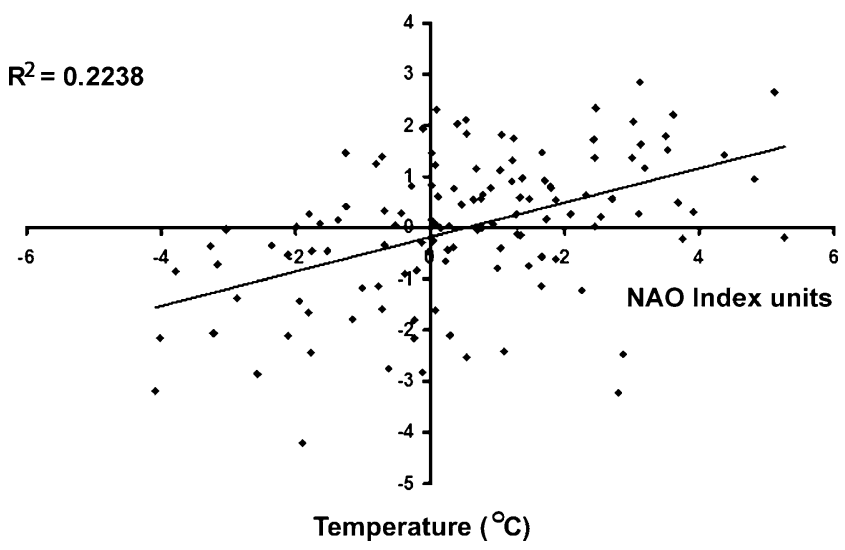

Fig. 3 Relationship between the deviations from the winter temperature means and the NAO $(p<0.001)$

where growth of microalgae is likely to occur, i.e. "growth days" with temperatures over $5^{\circ} \mathrm{C}$, has shifted significantly $(p<0.001)$ (Fig. 2), whereby the winter and autumn temperatures are clearly warmer. The deviations in temperature from the winter mean for all years are significantly correlated $(p<0.001)$ with the North Atlantic Oscillation (NAO) index, as can be seen in Fig. 3. Examples of especially high values are found in the years 1995 and 2003 and especially low values in the years 1985-1987.

\section{Currents}

The prevalent water transport patterns of the German Bight can be represented by two leading EOFs, which represent $87 \%$ of the total variability of water transport (Fig. 4a, b). While pattern 1 (explained $70 \%$ of the variance) represents an anomaly for the water transported roughly parallel to coasts, pattern 2 (explained $17 \%$ of the variance) describes an intensification/weakening of advection primarily from the north-western North Sea towards Helgoland. Note that generally in both patterns, flows are the strongest offshore, in contrast with known current velocities which are greatest inshore.

The magnitude of pattern 2 is positively correlated with Secchi disc depth and salinity and negatively correlated with temperature, phosphate, silicate and dissolved inorganic nitrogen. This is consistent with the suggestion that pattern 2 controls whether Helgoland is influenced either by more offshore or by more coastal waters, compared to the mean conditions. Figure 5 shows the PCs of the transport patterns (i.e. the magnitude). These patterns show that transport conditions between the late 1970s and around 1995 differ from those for other periods. From 1958 to 1975, values of PC1 were positive $29 \%$ of the time and negative $71 \%$ of the time. This situation was nearly reversed in the period 1976-1995 (66\% positive values and 34\% negative values). A similar shift can be identified for PC2 around 1980. Before 1980, its value was positive $61 \%$ of the time, and from 1980-1995, this percentage declined to $26 \%$.

To characterise the amount of water transport through the German Bight, we calculated the time series of fluxes across the three transects shown in Fig. 4c. The mean water budget of the German Bight is governed by an inflow across transect 1 and outflows across transects 2 and 3 (cf. Dahlgaard 1995). Transects 1 and 2 were chosen to closely resemble the time series of $\mathrm{PC} 1$ and $\mathrm{PC} 2$ and are closely oriented on the topographic conditions (Fig. 5).

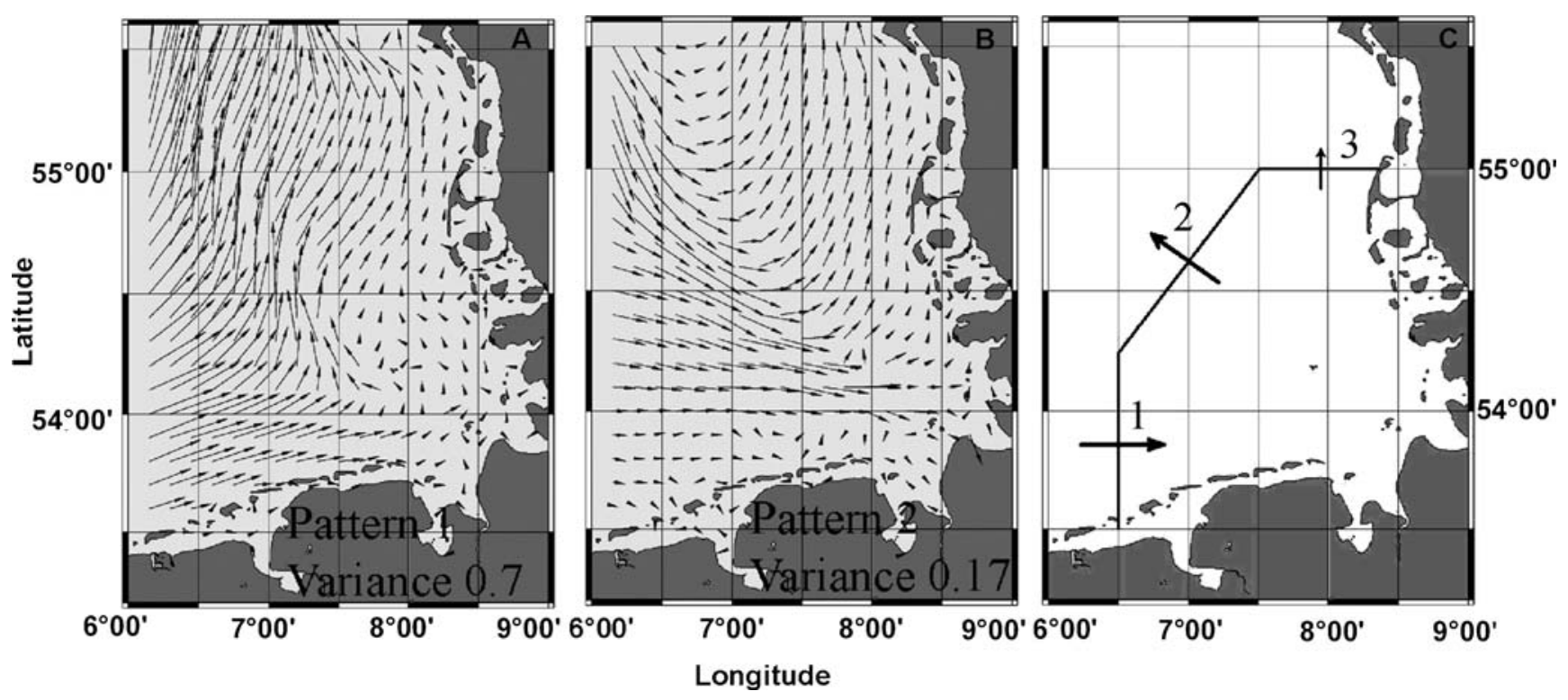

Fig. 4 a First EOF of residual flow (70\% explained variance), b second EOF of residual flow (17\% explained variance) and $\mathbf{c}$ investigation area with three transects, used to calculate water fluxes 


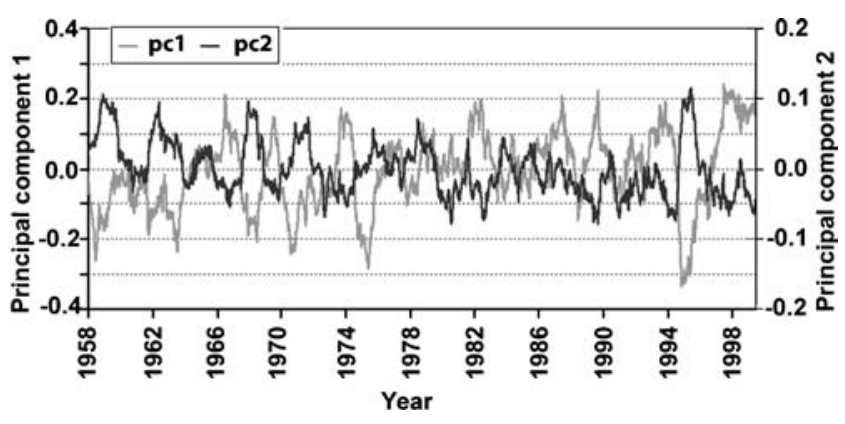

Fig. 5 Principal components (annual running means) of residual transports

In the period 1958-1977, the mean inflow across transect 1 amounted to about $32,000 \mathrm{~m}^{3} \mathrm{~s}^{-1}$, while during 1978-1995, the mean inflow was about $41,000 \mathrm{~m}^{3} \mathrm{~s}^{-1}$. Accordingly, the total mean outflow across transects 2 and 3 increased by $9,000 \mathrm{~m}^{3} \mathrm{~s}^{-1}$, with transect 2 accounting for the major part of about $8,000 \mathrm{~m}^{3} \mathrm{~s}^{-1}$. Thus, according to the numerical hindcast of the North Sea flow regime, starting in the late 1970s, water inflows from the south-west to the German Bight and corresponding flushing rates increased by nearly $30 \%$. These new water flow conditions prevailed for at least 15 years until 1995. An intensification of the circulation in the North Sea in the period 1958-1998 was also found by Siegismund (2001), based on simulations with the 20-layer, 3D baroclinic model HAMSOM. According to his work, the gross influx to the International council for the exploration of the sea (ICES) box covering the German Bight has increased by about $20 \%$, which he attributed to a changing wind climate.

\section{Salinity}

The salinity at Helgoland Roads shows a positive trend from 1962 to date. High-salinity events are related to the influx of North Sea water, and low-salinity events are

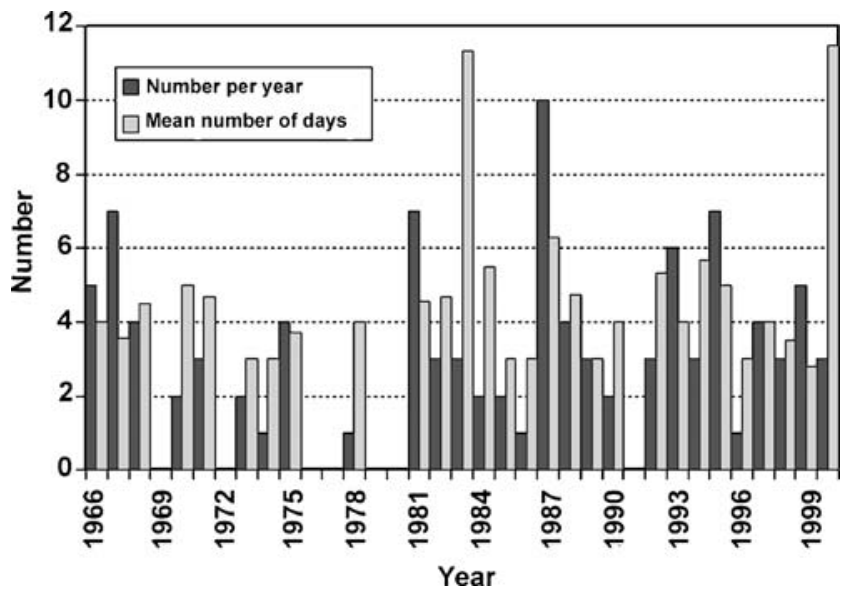

Fig. 6 Total number of freshwater events and mean number of days for an event for the years 1966-2000 related to coastal water influx at Helgoland Roads, mainly controlled by transport pattern 2 described above. However, the long-term trend of increasing salinity (Raabe and Wiltshire 2008) cannot be explained easily. This trend possibly results from stronger flushing rates through the German Bight. Stronger flushing rates combined with a constant freshwater inflow from coasts and rivers may lead to increased salinity values. Additionally, preliminary evidence shows that the flow through the English Channel also has changed substantially in the last 45 years, bringing more Atlantic water into the North Sea (M. Scharfe, personal communication).

The complexity of interactions in a marine environment are reflected by the fact that, despite the positive trend in salinity, the number of high-salinity events $(>34)$ remained constant. In contrast, the number of low-salinity events increased sharply at the beginning of the 1980s (Fig. 6). Low-salinity events are defined by a pronounced decrease in salinity by at least 2 within 1 day and are accompanied by an increase in silicate and nitrate concentrations. These "extreme" high-salinity days and freshwater events occur predominantly in the winter and spring months and are governed by very special wind conditions, whereas the extreme decrease of salinity is caused by an accumulation of freshwater near the coasts and afterwards the concentrated transport of this freshwater body to Helgoland.

Investigations of Siegismund and Schrum (2001) showed a pronounced change in the wind direction to the south-west in the eastern part of the North Sea in February and March since 1988. The same investigation with the wind situation only at Helgoland over the complete year

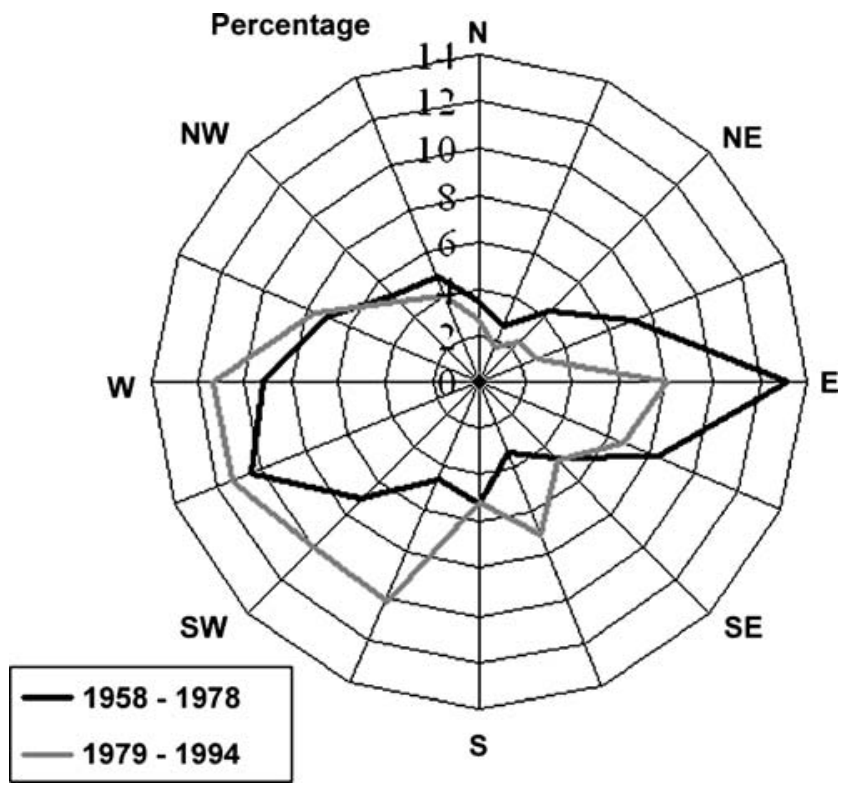

Fig. 7 Relative frequencies of wind directions for the time period before and after 1978 
shows the same changes, but it already starts in the late 1970s. The relative frequencies of the wind directions for the time period before and after 1978 are shown in Fig. 7. This shift may also be the reason for an increased number of freshwater events during that time.

\section{Nutrients}

At Helgoland Roads, a steady decrease in all nutrients since the early 1980s has been observed. This is likely due to a reduction in nutrient input (Hickel et al. 1993; van Beusekom 2004; van Beusekom et al. 2008) and also due to the fact that the current direction is less influenced by coastal waters, and more open North Sea water reaches the site than 45 years ago (Fig. 6). Figure $8 \mathrm{a}-\mathrm{d}$ shows the nutrient trends for nitrate, ammonium, phosphate and silicate. There is a significant decrease in ammonium and phosphate concentrations which are inversely correlated with Secchi depth and salinity trends (Wiltshire et al. 2008;
Raabe and Wiltshire 2008). Silicate, in particular, is interesting because a significant upwards shift in the concentrations was observed in the late 1970s correlated to other North Sea data at the time and perhaps was related to a combination of increased runoff from rivers and the input from highly saline Atlantic water (Raabe and Wiltshire 2008). Since then, the silicate concentrations have been steadily decreasing. One of the key questions is how these changes affect the carrying capacity of the system and what influence changes in nutrient ratios have on primary production.

\section{Bacteria and Viruses}

As described above, microbiological investigations at Helgoland Roads have recently been re-started. Evaluations of bacterial populations (1996-1999; weekly) and intermittent campaigns show that the phytoplankton and bacteria community exhibit pronounced seasonality (Gerdts et al.
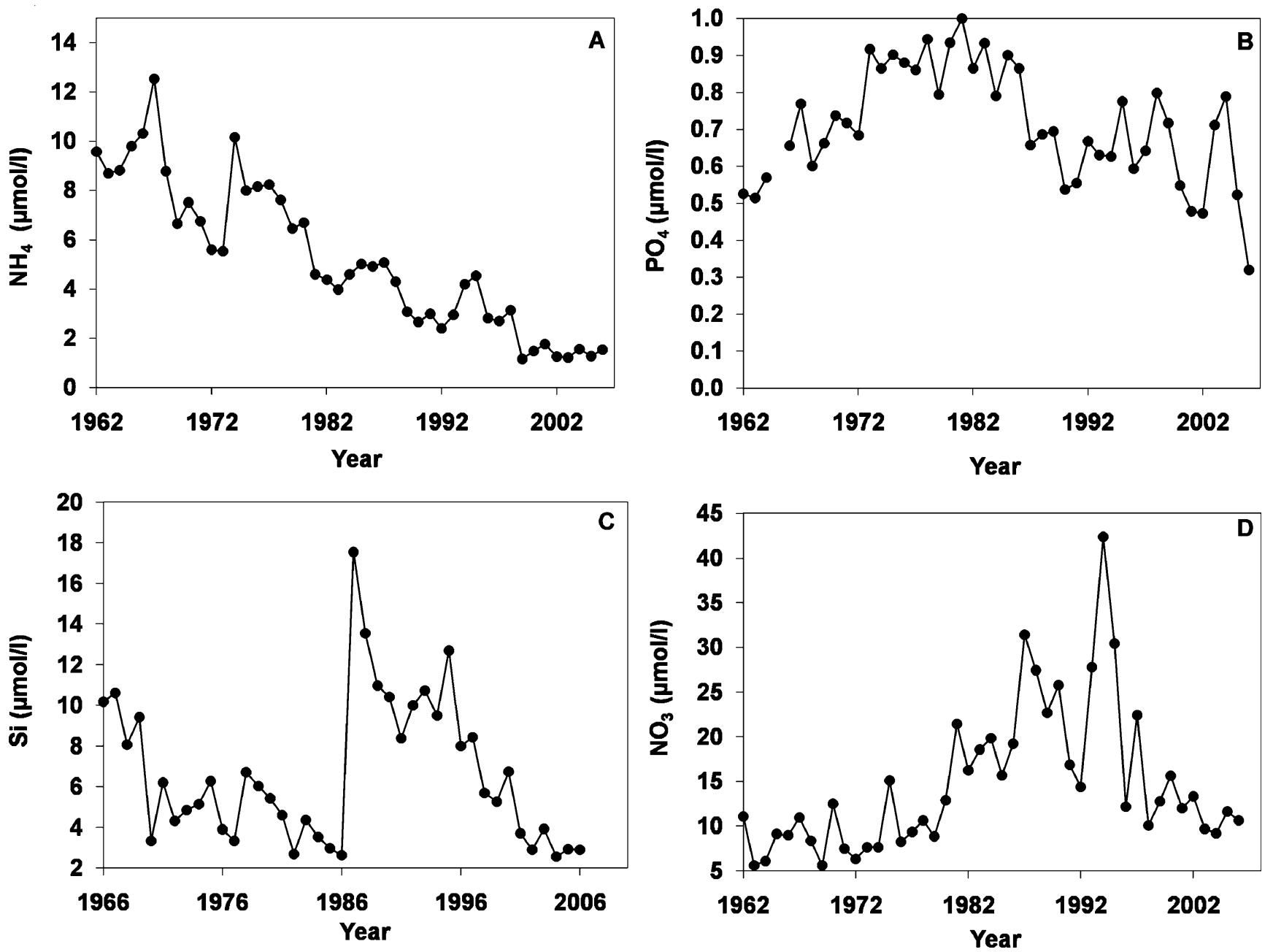

Fig. 8 Annual means of macronutrient concentrations $\left(\mu \mathrm{mol}^{-1}\right)$ in surface water at Helgoland Roads. a Ammonium, b phosphate, $\mathbf{c}$ silicate and d nitrate 
2004). A direct dependency on abiotic and biotic factors has been shown (Fig. 9; Sapp et al. 2007).

Electron microscopy studies of Helgoland Roads samples have shown a high diversity of bacteriophages and some conspicuous morphotypes (Fig. 10) in the pelagic waters (including Myoviruses, Siphoviruses and Podoviruses). All host bacteria belong to the Gammaproteobacteria (Wichels et al. 1998). Phage distributions with high virioplankton diversity (Fig. 11) were also found to be seasonal for Helgoland Roads following the bacterioplankton seasonality (Fig. 12). Low numbers of phages and bacteria were found during the winter and high numbers were detected from May to October. Thus, it remains to be seen how global change will affect these organisms which are at the base of the North Sea ecosystem and, in particular, whether the seasonality of viruses and bacteria will shift due to the observed temperature changes. Warming could facilitate invasions of tropical viruses and accelerate the spread of human pathogens into southern and even northern Europe (Ward and Lafferty 2004).

\section{Pelagic Microalgae}

When considering phytoplankton as pivotal organisms in temperate food webs, the timing of the spring bloom is of great importance. Wiltshire and Manly (2004) showed that

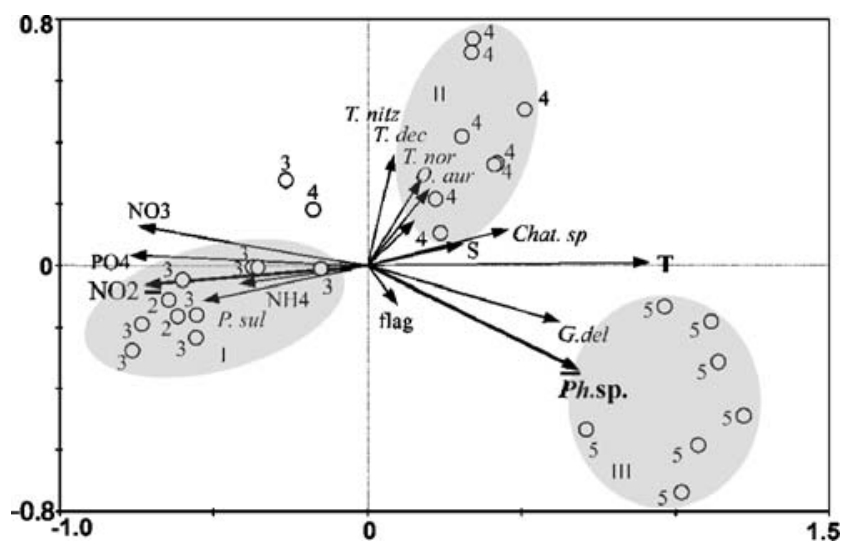

Fig. 9 Canonical correspondence analysis (CCA) biplot of intersample distances of DGGE fingerprints of the free-living bacterial community (samples from Helgoland Roads; 2004) using phytoplankton species cell counts of flagellates (flag), T. nitzschioides (T. nitz), $P$. sulcata (P. sul), O. aurita (O. aur), Thalassiosira nordenskiöldii (T. nor), Thalassiosira decipiens (T. dec), G. delicatula (G. del), Chattonella spp. (Chat. sp.) and Phaeocystis spp. (Ph. sp.), salinity (S), temperature $(\mathrm{T})$, nitrate $\left(\mathrm{NO}_{3}\right)$, nitrite $\left(\mathrm{NO}_{2}\right)$, ammonium $\left(\mathrm{NH}_{4}\right)$ and phosphate $\left(\mathrm{PO}_{4}\right)$. Circles indicate free-living communities. Numbers near the symbols indicate the month of sampling (2 February, 3 March, 4 April, 5 May). Arrows reflect the direction of increasing values of the respective variable, the length of arrows indicates the degree of correlation of the variable with community data. Significant variables are indicated by bold arrows (with arrowheads underlined), groups I, II and III of communities are indicated by grey background (from Sapp et al. 2007)
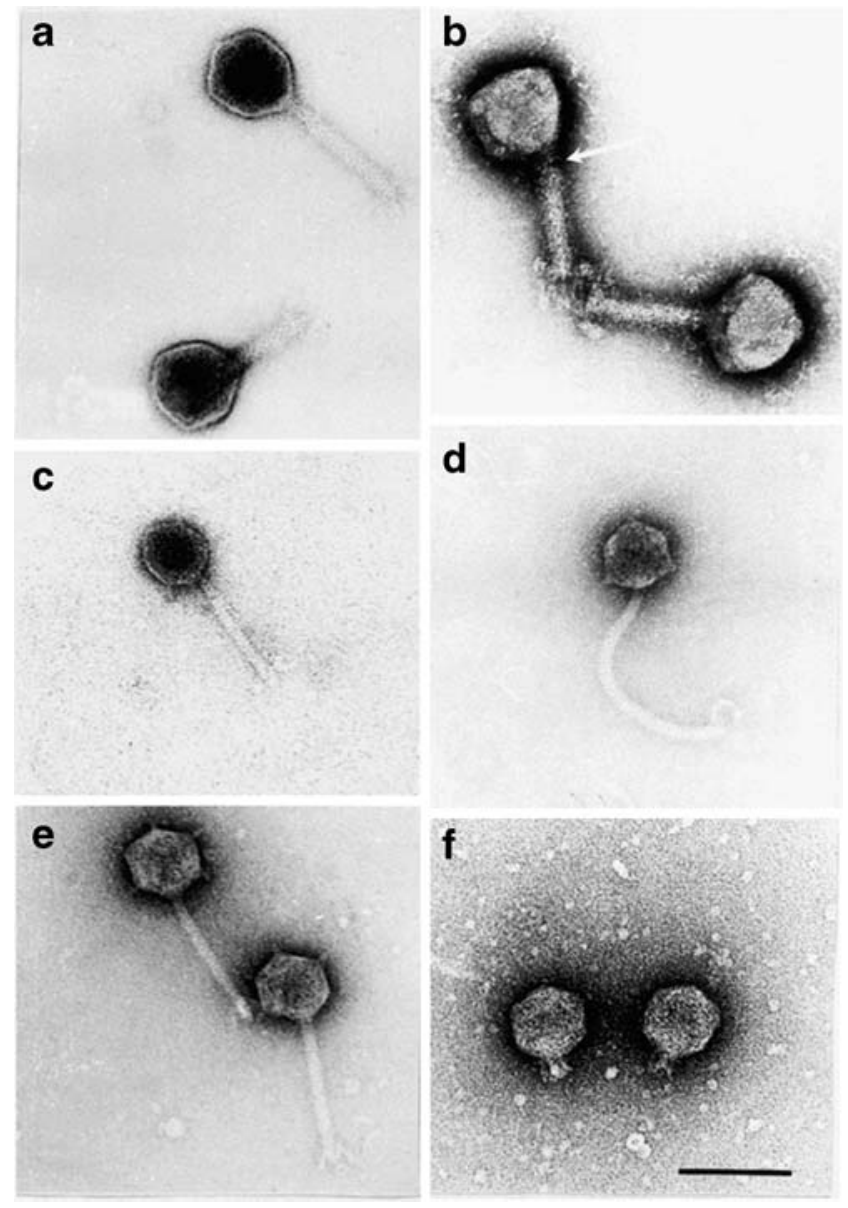

Fig. 10 Electron micrographs of a Myoviridae, morphotype 1: head without antennae; short appendages on the tail (phage H106/1); b Myoviridae, morphotype 2: collar-like structure between head and tail (see arrow), short appendages on the tail (phage H7/2;15); c Siphoviridae, morphotype 1: head and tail without appendages (phage 10-77a); d siphoviridae, morphotype 2: knob-like appendages on the head, tail with a hook at the end (phage1168c); e Siphoviridae, morphotype 3: knob-like appendages on the head, tail with short appendages (phage H105/1); f Podoviridae, morphotype 1 (phageH100/1). Bar represents $100 \mathrm{~nm}$

the spring bloom came significantly later in the time period 1962 to 2000. However, using all data available from 1973 to 2006, Wiltshire et al. (2008) showed that even though nutrient levels, temperature, underwater light climate and wind speeds have all changed at Helgoland Roads, the timing of the spring bloom has hardly changed. They showed that the bloom comes later in warmer years but that this correlation did not translate into significantly later blooms from 1975 to 2006, even after the regime shift of the late 1980s (Edwards et al. 2002; Weijerman et al. 2005).

Copepod densities in winter or those in the preceding autumn did not show a significant correlation with the phenology of the spring bloom. However, the first analyses of microalgal species diversity show that there have been changes in species composition with a significant increase 
Fig. 11 Virioplankton in water samples near Helgoland. Sampling April to June 2001. Bar represents $80 \mathrm{~nm}$
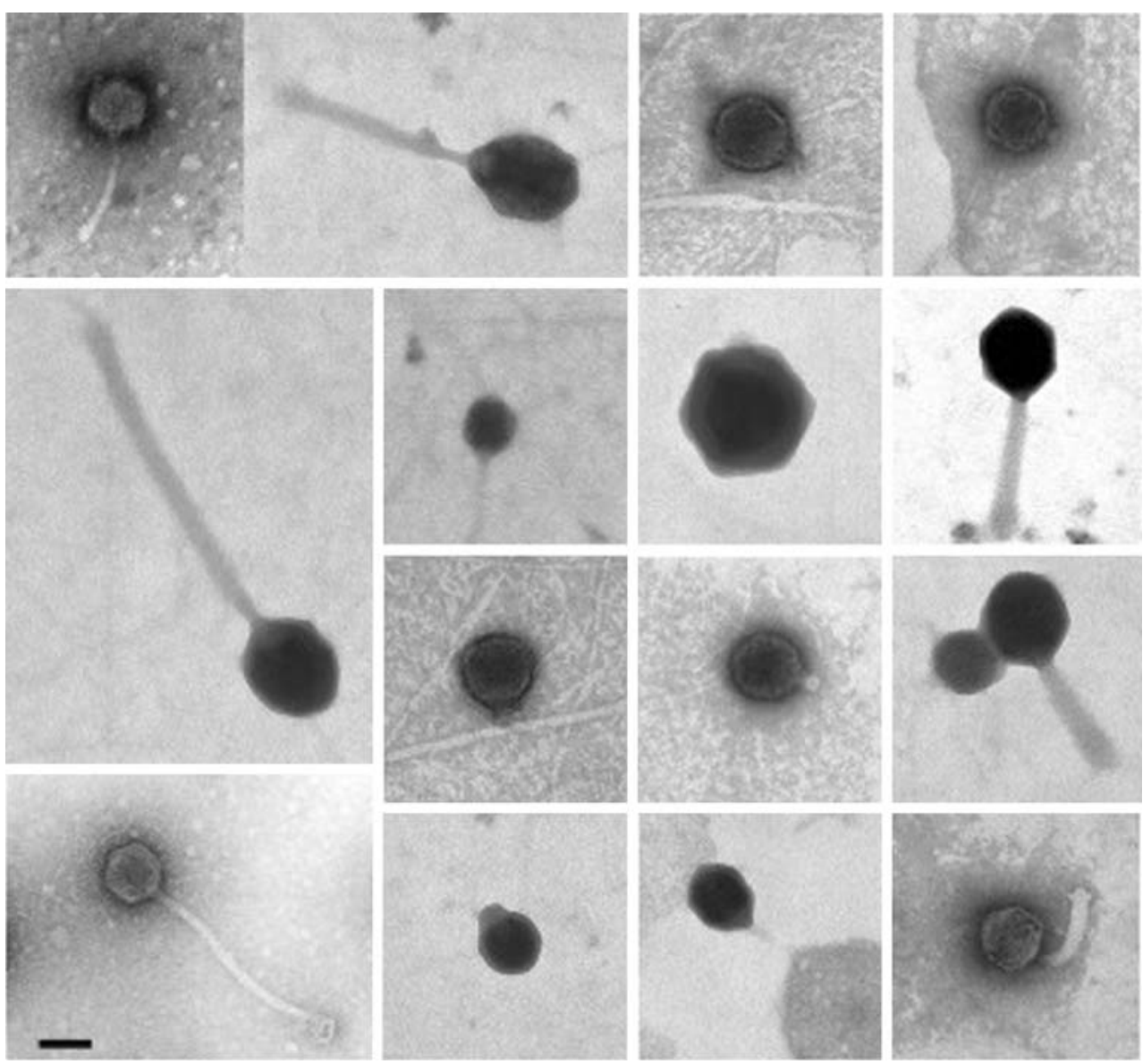

in the numbers of large heavily silicified diatoms (e.g., Coscinodiscus wailesii, Guinardia delicatula) which are difficult for copepods to consume (Roy et al. 1989). Thus, even though phytoplankton bloom dynamics have hardly changed over the time period examined, in such a turbulent system, increasing blooms of inedible diatoms as a result of higher grazing rates can be expected. Hence, it remains to

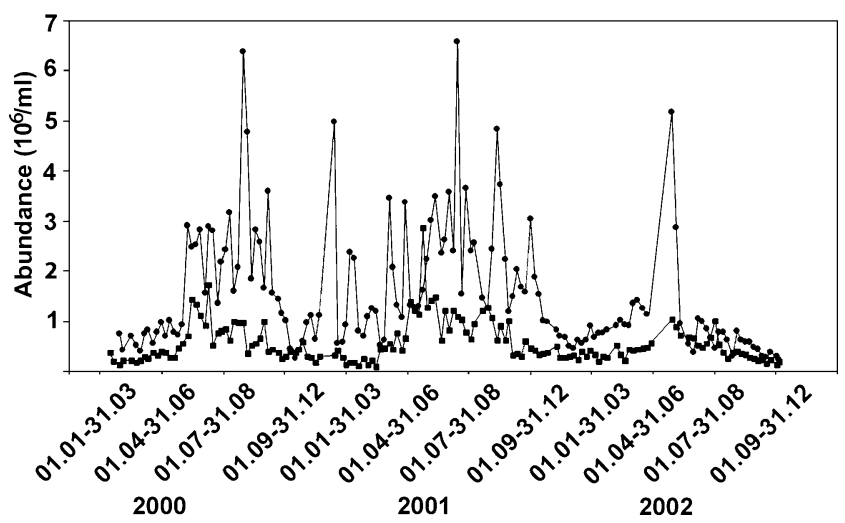

Fig. 12 Bacterioplankton (AODC) and Virioplankton (VLP) total counts from weekly samples at Helgoland; circles viral counts, squares bacterial counts be seen how much longer the system will remain relatively unchanged and whether species shifts have occurred.

As with all species counts over longer time periods, the number of species seen at Helgoland Roads has increased substantially, simply because the number of observations has increased and also the instrumentation has improved. Phytoplankton species have also been transported into the North Sea system from all over the world in the past 45 years. At Helgoland Roads, this includes, for example, C. wailesii and Odontella sinensis. It is not known whether these two diatoms have had any effect on the food web, although the former is not necessarily a good source of food for copepods (Roy et al. 1989; Jansen 2008). Because of the volume of data, work is just beginning on the species data. Although calculations of biodiversity on the complete set of species are difficult, some very interesting changes in species have been observed. One example is the cooccurrence of the diatoms G. delicatula, Thalassionema nitzschioides and Odontella aurita (Fig. 13) and a widening of the time period of occurrence of $G$. delicatula. This is interesting because $G$. delicatula has been shown to be adapted to warmer higher temperatures unlike the other two species (Schwaderer 2006). Moreover, it is less likely to be eaten by zooplankton as it is heavily silicified. 


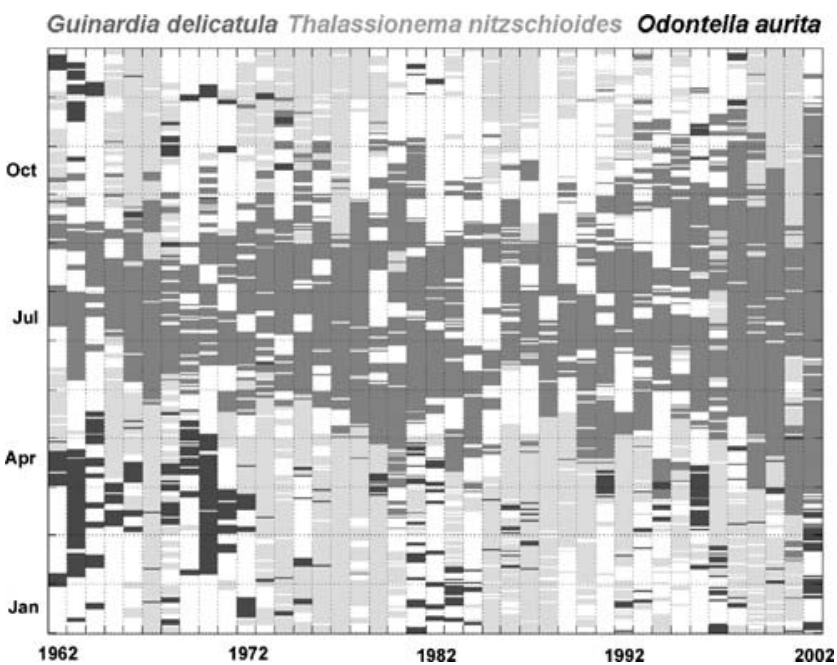

Fig. 13 Co-occurrence patterns of the diatoms G. delicatula, T. nitzschioides and $O$. aurita at the Helgoland Roads between 1962 and 2002. Threshold for inclusion of a record in the matrix was 120 cells $1^{-1}$

Another microalga which has exhibited changes is the diatom Paralia sulcata, which has a wide distribution and is often found in both planktonic and benthic microalgal communities of temperate coastal waters (Gebühr et al. 2009). P. sulcata does not typically form large blooms and is a cold water winter species which is steadily increasing. From 1968 onward, P. sulcata occurred at Helgoland Roads only in the autumn, winter and early spring, but since 1997, this alga also occurs during summer.

Multivariate statistical analysis showed that $P$. sulcata is a typical winter alga which is significantly negatively correlated with warmer water temperatures and high light conditions and positively correlated with higher amounts of nutrients, especially silicate and phosphate concentrations (Gebühr et al. 2009). Thus, P. sulcata is adapted to low light conditions with cooler water temperatures and higher concentrations of nutrients which are typical winter conditions for temperate waters such as Helgoland Roads. The shift in the occurrence of $P$. sulcata, which seems to be correlated with warmer water temperatures and higher Secchi depths, is also seen in the change in the niche position and niche breadth of $P$. sulcata from 1968 to 2005 (Fig. 14). The niche position and niche breadth of $P$. sulcata showed a significant shift from 1968 to 2005 with large inter-yearly differences. From 1980 to 1996, the niche breadth was very small, indicating a more specialised ecological niche. But from 1997 to 2005, the niche position decreased, and the niche breadth was significantly wider, typically reflecting the more generalised ecological niche of $P$. sulcata (Gebühr et al. 2009). Due to the fact that $P$. sulcata now also appears in the summer period in the water column, this diatom could play an important role as a food source for pelagic grazers.

\section{Zooplankton}

Unlike for the phytoplankton at Helgoland Roads, for the zooplankton time series, nearly all of the counting and analysis of mesozooplankton has been carried out by one person since 1975. Macro-zooplankton data were counted by a larger set of people (see Greve et al. 2004 for details). Therefore, the database for mesozooplankton is consistent, and earlier observations can be compared to later ones without bias. Many examples of changing phenology (Greve and Reiners 1988; Greve et al. 2005; Wiltshire et al. 2008) have shown strong correlations between the sea surface temperature and the occurrence of several species, with higher temperatures usually leading to an earlier occurrence of the zooplankton species. Furthermore, several changes in the species composition have been noted, most conspicuously the increased abundance of the cladoceran Penilia avirostris (Johns et al. 2005), the changing species composition within the genus Calanus (Helaouet and Beaugrand 2007) and the invasion of the ctenophore $M$. leidyi (Boersma et al. 2007).

Until now, no analysis of zooplankton diversity has been carried out. We found that diversity within copepods is highly variable. Shannon-Wiener Diversity $\left(H^{\prime}\right)$ was computed based on weekly averages of the densities of 11 copepod species, thus ranging between 0 (complete dominance of one taxon only) and $\log _{10} 11=1.04$ with equal abundances of all taxa. Figure $15 \mathrm{a}$ shows the average seasonal change in $H^{\prime}$ with the highest values in winter and lower ones during the growing season, which is mainly caused by a dominance of the smaller calanoid species Acartia clausi and Temora longicornis at that time. More interesting, however, is the change in copepod diversity

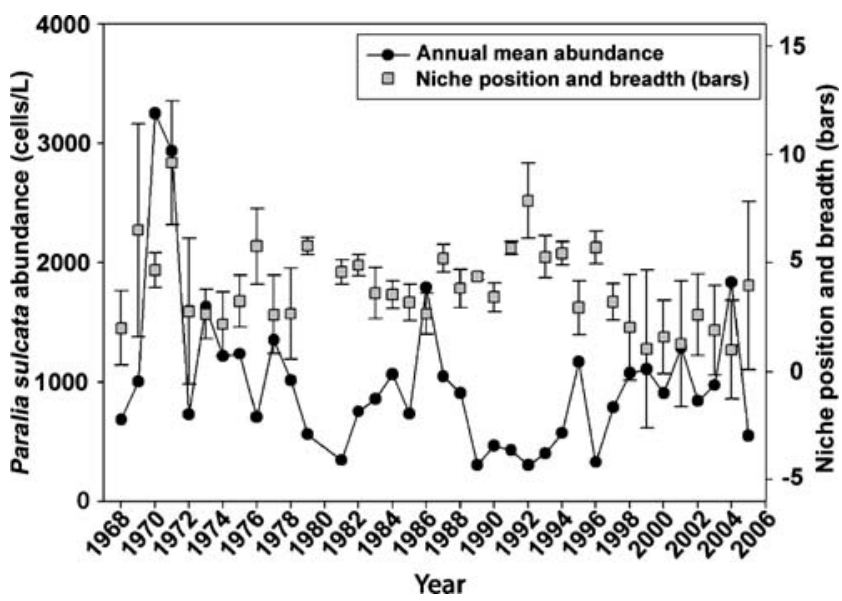

Fig. 14 Annual mean abundance, niche position and niche breadth (error bars) of the diatom P. sulcata from 1968 to 2005 (surface waters Helgoland Roads). Error bars $= \pm 1 \mathrm{SD}$, data points $=$ means of all annual samples 

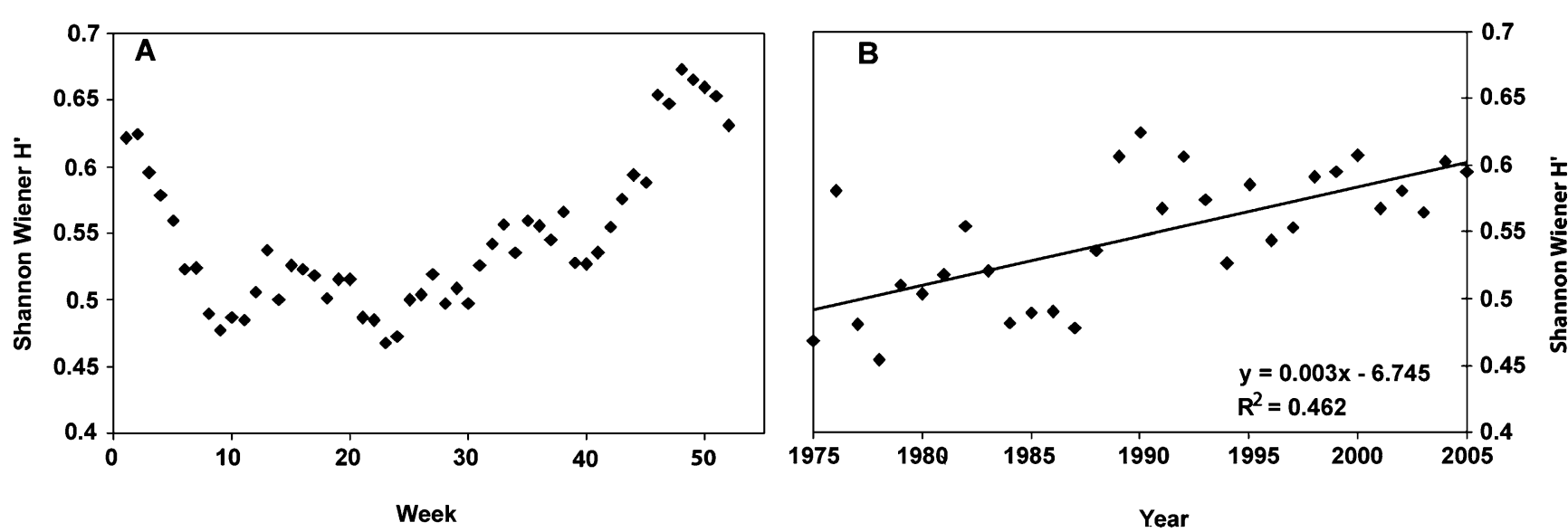

Fig. 15 a Changes in copepod diversity (expressed as Shannon-Wiener Diversity $H^{\prime}$ ) averaged over all sampling years (1975-2005) and b time plot of the average yearly diversity. The change in diversity over the years is significant at $p<0.001$

over the years (Fig. 15b). Since the beginning of the time series, the mean yearly diversity has increased significantly, showing that individual species have become less dominant. Most likely, this may have affected the phytoplankton community, as an increasing diversity of grazers would lead to changes in the predation pressure on the total community. Currently, phytoplankton diversity is being calculated to test this hypothesis.

\section{Macroalgae}

Both losses and additions to the macroalgal flora have been identified during the last 100 years (Bartsch and Kuhlenkamp 2000). The years from 1845 to 1935 can be classified as a low-nutrient phase and the period from 1959 to 1998 as a high-nutrient phase in the German Bight. Comparing the species richness in these phases and also with the whole time interval, it is evident that macroalgal species richness has not changed, although species composition has changed (Fig. 16).

The number of green algal species clearly increased, and the number of brown algal species has decreased after 1959. Both of these criteria potentially reflect the higher nutrient concentrations in the water at Helgoland (see nutrients above), and temperature effects may also be important. Twelve brown and red algal species, which were already rare around 1900, totally disappeared from Helgoland later on, while other more warm-temperate species reduced their presence to their microstage. Two intertidal warm-temperate brown algae were not recorded for decades but reappeared after 1999 (Bartsch and Kuhlenkamp 2000). Some neobiota (Sargassum muticum, Mastocarpus stellatus) have considerably altered the benthic habitats. A few recent additions to the flora are considered to be range extensions of more warm-temperate species and are still rare (Bartsch and Kuhlenkamp 2009).
Considerable changes have been observed in the biomass and depth distribution of the two sublittoral kelp species Laminaria hyperborea and Saccharina latissima and associated red algae since 1968 (Pehlke and Bartsch 2008). This could be attributed to an increase in water clarity and an associated change in light penetration depths that has been observed by Wiltshire et al. (2008). Despite these floristic changes, most of the intertidal biotopes that were recorded around 1900 are still present (Bartsch and Tittley 2004), so that the major structuring components have not been lost. However, a further increase in temperatures could affect the sublittoral kelp forest which constitutes $99 \%$ of the macroalgal habitat at Helgoland (Bartsch and Kuhlenkamp 2009). A newly established (since 2003) quantitative time series in the intertidal area now allows a detailed analysis of spatio-temporal change of all macroalgal species.

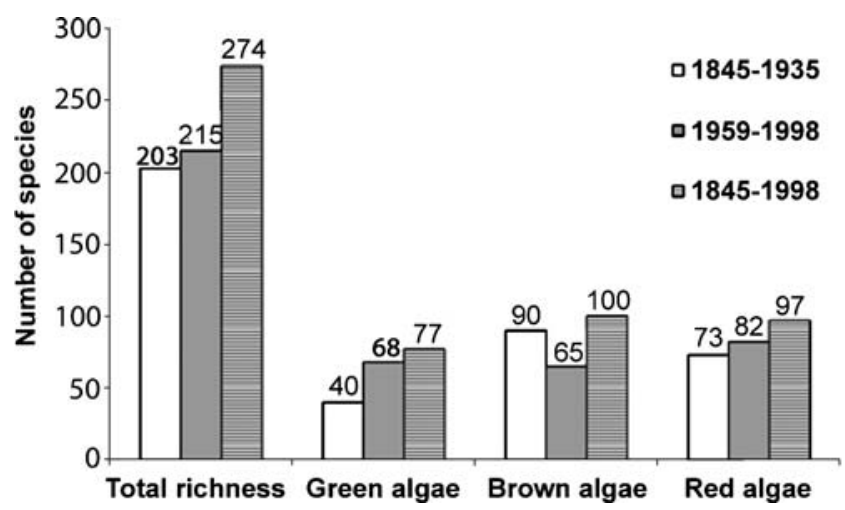

Fig. 16 Development of macroalgal species richness at Helgoland for three periods between 1845 and 1998 (after Bartsch and Kuhlenkamp 2000). White bars species numbers between 1845 and 1935, grey bars 1959-1998, and striped bars 1845-1998 


\section{Zoobenthos}

More than 30 macrofaunal species have been newly recorded at Helgoland Roads over the last 20 years. There has been a distinct shift in benthic animals towards southern species and an increase in local species diversity. However, many new species are not only warm water species, and only some are known to be human introductions. How neobiota affect other species in the system is as yet unclear. The effects could range from invasive (e.g. Mnemiopsis, Caprella) to simply inhabiting a previously unoccupied niche (e.g. the gastropod Elysia viridis and a number of amphipods). Direct competition was demonstrated between the immigrant isopod Idotea metallica (at Helgoland Roads since 1994) and its native congener Idotea baltica. Nevertheless, segregation by (micro-) habitat was found to allow for a long-term coexistence of these two species (Franke et al. 1999; Gutow et al. 2007).

The invasive Japanese oyster (Crassostrea gigas) was already a big problem in the Wadden Sea, but over the past 2 years, it has become even more common also at Helgoland Roads. Its success is related to a combination of factors including a warmer climate. The dramatic decline of the Helgoland population of the European lobster (Homarus gammarus) about 50 years ago was also related to a combination of factors. Serious obstacles to its recovery include low density of individuals (Allee effect), harmful effects of increased winter temperatures on the timing of larval release and competition by the edible crab (Cancer pagurus) which seems to have encroached upon the lobster's niche (Franke and Gutow 2004; Schmalenbach, personal communication).

\section{Overall Assessment of Change at Helgoland Roads}

The hydrographic environment around Helgoland has changed considerably over the past 45 years with changes in currents around 1975-1977. Starting in the late 1970s, water inflows from the south-west to the German Bight increased, and corresponding flushing rates increased by nearly $30 \%$. These changes in water flow conditions prevailed for at least 15 years until 1995 . The salinity at Helgoland Roads shows an increase from 1962 to date, high-salinity events at Helgoland are related to the transport of North Sea water, and low-salinity events are related to coastal water transport. The wind fields have also shifted considerably at Helgoland, an aspect which is important when considering changes in species diversity in the waveaffected intertidal zone. The water temperature at Helgoland Roads has increased significantly by $1.67^{\circ} \mathrm{C}$ since 1962 , resulting in an annual increase of around $0.037^{\circ} \mathrm{C}$ year $^{-1}$ (Wiltshire et al. 2008). Both the winter and summer temperatures have increased. We know that temperature has influenced the seasonal growth of phytoplankton at Helgoland, i.e. the number of "growth" days (days over $5^{\circ} \mathrm{C}$ ) for phytoplankton have been extended significantly, whereas surface irradiance has not changed significantly and cannot be related to the shift in growth time of the microalgae (Wiltshire et al. 2008).

The functioning of the ecosystem and species diversity will largely be governed by physico-chemical parameters, i.e. light, temperature and nutrients. Consequently, these must be taken into account when comparing biological parameters and considering shifts in diversity at Helgoland Roads.

A major shift in the hydrographic parameters and microalgae was seen at Helgoland around 1988 (Wiltshire et al. 2008; Schlüter et al. 2008) when a sharp decline in total winter diatom densities was observed, after which they increased substantially (Wiltshire et al. 2008). This is consistent with the results from studies by Edwards et al. (2002), Weijerman et al.(2005) and Schlüter et al. (2008), who analysed 28 abiotic and 50 biological time series in the North Sea and Wadden Sea and identified a major regime shift around 1988. Given that the German Bight around Helgoland is a highly dynamic system which has undergone considerable change in the last 30 years, it is interesting to note how resilient the system is when considering the phytoplankton spring bloom. Even though nutrient levels, temperature, the underwater light climate and wind speeds have all changed and there has been a regime shift affecting the system, the timing of the spring bloom has hardly changed. Analysis of species diversity shows that, over these years, there was a significant increase in the numbers of large diatoms (e.g. G. delicatula and $C$. wailesii) which are difficult for copepods to graze (Roy et al. 1989; Jansen 2008).

Over the whole time period, large shifts in zooplankton diversity were observed. There has been an increase in abundance of the cladoceran P. avirostris (Johns et al. 2005). Changes in species composition within the genus Calanus (Helaouet and Beaugrand 2007) were observed, and the invasion of the ctenophore $M$. leidyi has been documented (Boersma et al. 2007; Faasse and Bayha 2006). Greve et al. (2004) showed strong correlations between the sea surface temperature and the occurrence of several species (e.g. Evadne sp., Solea sp.) with higher temperatures usually leading to an earlier occurrence of zooplankton.

Of all of the variables determined at Helgoland, the assessment of bacteria and viruses suffered from the greatest methodological problems (e.g. plate counts), and thus, it is difficult to use the past data. However, from weekly DGGE and RISA analyses of water from 1996 to 1999 and other seasonal campaigns, it has been observed that the bacterial community displays a pronounced 
seasonality (Gerdts et al. 2004) and that it has a direct dependency on abiotic and biotic factors (Sapp et al. 2007).

In terms of macro-flora and -fauna, the most discussed aspect is the introduction of 'warm water aliens', i.e. species which have recently arrived in the system and which would normally die under colder conditions but which now can persist and multiply under the warmer conditions. Examples of these at Helgoland Roads are clearly found in the larger organisms and include the brown seaweed S. muticum (Reichert and Buchholz 2006) and the isopod I. metallica (Gutow and Franke 2001). Such species are usually viewed negatively as it is assumed that they may compete with or even displace indigenous species. However, S. muticum has been shown to provide a refuge for small fish and can be seen as a gathering point for plankton-seemingly making it a positive introduction to the Wadden Sea by increasing habitat value (Polte and Buschbaum 2008). How introductions and especially warm water species integrate into the ecosystem is the subject of our ongoing studies (Buschbaum 2005; Cook et al. 2007; Kochmann et al. 2008).

Acknowledgements We wish to thank all the people who have ensured that the Helgoland Roads time series has been kept alive over the past 45 years. These people range from the crews of the research vessels, counting personnel, people who carried out taxonomic investigations and those who did the chemical analyses. We also thank the State Agency for Nature and Environment (LLUR) of Schleswig-Holstein for their continued support. We also thank those who had the foresight to archive the data and set up models.

\section{References}

Alonso, C. and J. Pernthaler. 2006. Concentration-dependent patterns of leucine incorporation by coastal picoplankton. Applied and Environmental Microbiology 72: 2141-2147.

Bartsch, I. and R. Kuhlenkamp. 2000. The marine macroalgae of Helgoland (North Sea): An annotated list of records between 1845 and 1999. Helgoland Marine Research 54: 160-189.

Bartsch, I. and R. Kuhlenkamp. 2009. Entwicklung der Makrophyten Vegetation bei Helgoland vor dem Hintergrund der Wasserrahmenrichtlinie. Bundesamt für Seeschiffahrt und Hydrographie (BSH), Hamburg. Meeresumwelt Aktuell: Nord- und Ostsee 1: 1-8.

Bartsch, I., R. Kuhlenkamp, K. Boos, and C. Gehling. 2004. Praxistest für das Makrophyten- und Miesmuschel-Monitoring bei Helgoland im Rahmen der WRRL: Küstengewässertyp Helgoland (N5). Flintbek: LANU.

Bartsch, I. and I. Tittley. 2004. The rocky intertidal biotopes of Helgoland: Present and past. Helgoland Marine Research 58: 289-302.

Beardsley, C., J. Pernthaler, W. Wosniok, and R. Amann. 2003. Are readily cultured bacteria in coastal North Sea waters suppressed by selective grazing mortality? Applied and Environmental Microbiology 69: 2624-2630.

Boersma, M., A.M. Malzahn, W. Greve, and J. Javidpour. 2007. The first occurrence of the ctenophore Mnemiopsis leidyi in the North Sea. Helgoland Marine Research 62: 153-155.
Boos, K., C. Buchholz, F. Buchholz, and L. Gutow. 2004. Projektbericht über die Zusammensetzung des Helgoländer Makrozoobenthos im Vergleich historischer und aktueller Quellen - Klassifizierungsvorschlag nach der WRRL und Empfehlungen zum Monitoring.

Buschbaum, C. 2005. Mass occurrence of an introduced crustacean (Caprella cf. mutica) in the south-eastern North Sea. Helgoland Marine Research 59: 252-253.

Cook, E.J., M. Jahnke, F. Kerckhof, D. Minchin, M. Faasse, K. Boos, and C. Ashton. 2007. European expansion of the introduced amphipod Caprella mutica Schurin 1935. Aquatic Invasions 2: $411-421$

Dahlgaard, H. 1995. Transfer of European coastal pollution to the Arctic: Radioactive tracers. Marine Pollution Bulletin 31: 3-7.

Edwards, M., G. Beaugrand, P.C. Reid, A.A. Rowden, and M.B. Jones. 2002. Ocean climate anomalies and the ecology of the North Sea. Marine Ecology Progress Series 239: 1-10.

Eilers, H., J. Pernthaler, J. Peplies, F.O. Glöckner, G. Gerdts, and R. Amann. 2001. Isolation of novel pelagic bacteria from the German Bight and their seasonal contributions to surface picoplankton. Applied and Environmental Microbiology 67: 5134-5142.

Faasse, M.A. and K.M. Bayha. 2006. The ctenophore Mnemiopsis leidyi A. Agassiz 1865 in coastal waters of the Netherlands: An unrecognized invasion? Aquatic Invasions 1: 270-277.

Feser, F., R. Weisse, and H. von Storch. 2001. Multidecadal atmospheric modelling for Europe yields multi-purpose data. EOS Transactions 82: 305-310.

Franke, H.-D. and L. Gutow. 2004. Long-term changes in the macrozoobenthos around the rocky island of Helgoland (German Bight, North Sea). Helgoland Marine Research 58: 303-310.

Franke, H.-D., L. Gutow, and M. Janke. 1999. The recent arrival of the oceanic isopod Idotea metallica Bosc off Helgoland (German Bight, North Sea): An indication of a warming trend in the North Sea? Helgoländer Meeresuntersuchungen 52: 347-357.

Freund, J., T. Pöschel, and K.H. Wiltshire. 2006. Markovsche Analyse nasser Gemeinschaften. In Irreversible Prozesse und Selbstorganisation, ed. T. Pöschel and L. Schimansky-Geier, 99-110. Berlin: Logos.

Gebühr, C., K. H. Wiltshire, N. Aberle, J. E. E. van Beusekom, and G. Gerdts. 2009. Influence of nutrients, temperature, light and salinity on the occurrence of Paralia sulcata at Helgoland Roads, North Sea. Aquatic Biology 7: 185-197.

Gerdts, G., A. Wichels, H. Döpke, K.-W. Klings, W. Gunkel, and C. Schutt. 2004. 40-year long-term study of microbial parameters near Helgoland (German Bight, North Sea): Historical view and future perspectives. Helgoland Marine Research 58: 230-242.

Grasshoff, K. 1976. Methods of seawater analysis. Weinheim: Chemie.

Greve, W., S. Prinage, H. Zidowitz, J. Nast, and F. Reiners. 2005. On the phenology of North Sea ichthyoplankton. ICES Journal of Marine Science 62: 1216-1223.

Greve, W. and F. Reiners. 1988. Plankton time-space dynamics in the German Bight North Sea: A systems approach. Oecologia 77: 487-496.

Greve, W., F. Reiners, J. Nast, and S. Hoffmann. 2004. Helgoland Roads meso- and macrozooplankton time series 1974 to 2004: Lessons from 30 years of single spot, high frequency sampling at the only off-shore island of the North Sea. Helgoland Marine Research 58: 274-288.

Gutow, L. and H.-D. Franke. 2001. On the current and possible future status of the neustonic isopod Idotea metallica Bosc. in the North Sea: A laboratory study. Journal of Sea Research 45: 37-44.

Gutow, L., S. Leidenberger, S. Boos, and H.-D. Franke. 2007. Differential life-history responses of two Idotea species (Crusta- 
cea: Isopoda) to food limitation. Marine Ecology Progress Series 344: 159-172.

Hass, H.-C. and I. Bartsch. 2008. Observing the coastal sea. In $A n$ atlas of advanced monitoring techniques, ed. R. Doerffer, F. Colijn, and J. van Beusekom, 50-35. Geesthacht: GKSS Research Centre.

Helaouet, P. and G. Beaugrand. 2007. Macroecology of Calanus finmarchicus and C. helgolandicus in the North Atlantic Ocean and adjacent seas. Marine Ecology Progress Series 345: 147-165.

Hennig, B.D., B.C. Cogan, and I. Bartsch. 2007. Hyperspectral remote sensing and analysis of intertidal zones: A contribution to monitor coastal biodiversity. In Geospatial crossroads@GI Forum, ed. A. Car, G. Griesebner, and J. Strobl, 62-73. Heidelberg: Wichmann.

Hervouet, J. M., and L. van Haren. 1996. TELEMAC2D Version 3.0 Principle Note. Rapport EDF HE-4394052B, Electricité de France, Département Laboratoire National d'Hydraulique, Chatou CEDEX.

Hickel, W. 1972. Kurzzeitige Veränderungen hydrographischer Faktoren und der Sestonkomponenten in driftenden Wassermassen in der Helgoländer Bucht. Helgoländer Wissenschaftliche Meeresuntersuchungen 23: 383-392.

Hickel, W., P. Mangelsdorf, and J. Berg. 1993. The human impact in the German Bight: Eutrophication during three decades (19621991). Helgoländer Wissenschaftliche Meeresuntersuchungen 47: 243-263.

Hoppenrath, M. 2004. A revised checklist of planktonic diatoms and dinoflagellates from Helgoland (North Sea, German Bight). Helgoland Marine Research 58: 243-251.

Hoppenrath, M., B. Beszteri, G. Drebes, H. Halliger, J.E.E. Beusekom, S. Janisch, and K.H. Wiltshire. 2007. Thalassiosira species (Bacillariophyceae, Thalassiosirales) in the North Sea at Helgoland (German Bight) and Sylt (North Frisian Wadden Sea)-A first approach to assessing diversity. European Journal of Phycology 42: 271-288.

IPCC. 2001a. Climate change 2001: Impacts, adaptation and vulnerability. In Intergovernmental panel on climate change third assessment report, ed. J.J. McCarthy, O.F. Canziani, N.A. Leary, D.J. Dokken, and K.S. White. Cambridge: Cambridge University Press.

IPCC. 2001b. Climate change 2001: The scientific basis. In Intergovernmental panel on climate change third assessment report, ed. J.T. Houghton, Y. Ding, D.J. Griggs, M. Nogouer, P.J. van der Linden, X. Dai, K. Maskell, and C.A. Johnson. Cambridge: Cambridge University Press.

IPCC. 2007. Summary for policymakers. In Climate change 2007: The physical basis. Contribution of working group 1 to the fourth assessment report of the intergovernmental panel on climate change, ed. S. Solomon, D. Qin, M. Manning, Z. Chen, M. Marquis, K.B. Averyt, M. Tignor, and H.L. Miller. Cambridge: Cambridge University Press.

Jansen, S. 2008. Copepods grazing on Coscinodiscus wailesii-A question of size? Helgoland Marine Research 62: 251-255.

Johns, D.G., M. Edwards, W. Greve, and A.W.G. John. 2005. Increasing prevalence of the marine cladoceran Penilia avirostris Dana 1852 in the North Sea. Helgoland Marine Research 59: 214-218.

Kistler, R.E., W. Kalnay, W. Collins, J. Woollen, M. Chelliah, M. Ebisuzaki, M. Kanamitsu, V. Kousky, H. van den Dool, R. Jenne, and M. Fiorino. 2001. The NCEP-NCAR 50-year reanalysis: Monthly means CD-ROM and documentation. Bulletin of the American Meteorological Society 82: 247-268.

Kochmann, J., C. Buschbaum, N. Volkenborn, and K. Reise. 2008. Shift from native mussels to alien oysters: Differential effects of ecosystem engineers. Journal of Experimental Marine Biology and Ecology 364: 1-10.
Lund, J.W.G., C. Kipling, and E.D. LeCren. 1958. The inverted microscope method of estimating algal numbers and the statistical basis of estimations by counting. Hydrobiologia 11: $143-170$

Pehlke, C. and I. Bartsch. 2008. Changes in depth distribution and biomass of sublittoral seaweeds at Helgoland (North Sea) between 1970 and 2005. Climate Research 37: 135-147.

Pernthaler, A. and J. Pernthaler. 2005. Diurnal variation of cell proliferation in three bacterial taxa from coastal North Sea waters. Applied and Environmental Microbiology 71: 46384644.

Petersen, W.H., H. Wehde, F. Krasemann, F. Colijn, and F. Schroeder. 2008. FerryBox and MERIS-Assessment of coastal and shelf sea ecosystems by combining in situ and remote sensing data. Estuarine and Coastal Shelf Science 77: 296-307.

Plüß, A. 2004. Das Nordseemodell der BAW zur Simulation der Tide in der Deutschen Bucht. Die Küste 67: 83-127.

Polte, P. and C. Buschbaum. 2008. Native pipefish (Entelurus aequoreus) promoted by the introduced seaweed Sargassum muticum in the Northern Wadden Sea, North Sea. Aquatic Biology 3: 11-18.

Raabe, T. and K.H. Wiltshire. 2008. Quality control and analyses of the long-term nutrient data from Helgoland Roads, North Sea. Journal of Sea Research 61: 3-16.

Reichert, K. and F. Buchholz. 2006. Changes in the macrozoobenthos of the intertidal zone at Helgoland (German Bight, North Sea): A survey of 1984 repeated in 2002. Helgoland Marine Research 60: 213-223.

Reichert, K., F. Buchholz, I. Bartsch, T. Kersten, and L. Giménez. 2008. Scale-dependent patterns of variability in species assemblages of the rocky intertidal at Helgoland (German Bight, North Sea). Journal of the Marine Biological Association (United Kingdom) 88: 1319-1329.

Reid, P.C., M.F. Borges, and E. Svendsen. 2001. A regime shift in the North Sea circa 1988 linked to changes in the North Sea horse mackerel fishery. Fisheries Research 50: 163-171.

Reid, P.C., B. Planque, and M. Edwards. 1998. Is observed variability in the long-term results of the Continuous Plankton Recorder survey a response to climate change? Fisheries Oceanography 7: $282-288$.

Roy, S., R.P. Harris, and S.A. Poulet. 1989. Inefficient feeding by Calanus helgolandicus and Temora longicornis on Coscinodiscus wailesii: Quantitative estimation using chlorophyll-type pigments and effects on dissolved free amino acids. Marine Ecology Progress Series 52: 145-153.

Sapp, M., G. Gerdts, K.H. Wiltshire, and A. Wichels. 2007. Bacterial community dynamics during winter-spring transition in the North Sea. FEMS Microbiology Ecology 59: 622-637.

Schlüter, M.H., A. Merico, K.H. Wiltshire, W. Greve, and H. von Storch. 2008. A statistical analysis of climate variability and ecosystem response in the German Bight. Ocean Dynamics 58: $169-186$.

Schwaderer, A.S. 2006. Missing links and experimental evaluation of phytoplankton growth and succession. Ph.D. Thesis University of Kiel. 193 pp.

Siegismund, F. 2001. Long-term changes in the flushing times of the ICES Boxes. Senckenbergia Maritima 31: 151-167.

Siegismund, F. and C. Schrum. 2001. Decadal changes in the wind forcing over the North Sea. Climate Research 18: 39 45.

Staley, J.T. and A. Konopka. 1985. Measurements of in situ activities of non- photosynthetic microorganisms in aquatic and terrestrial habitats. Annual Review of Microbiology 39: 321-346.

Thiemann, S., and I. Bartsch. 2005. Biotope mapping of the intertidal zone of Helogoland (North Sea) using hyperspectral remote sensing images. Proceedings of the Eighth International Confer- 
ence on Remote Sensing of Marine and Coastal Environments, 19. Halifax, Nova Scotia

van Beusekom, J.E.E. 2004. A historic perspective on Wadden Sea eutrophication. Helgoland Marine Research 59: 45-54.

van Beusekom, J.E.E., S. Weigelt-Krenz, and P. Martens. 2008. Longterm variability of winter nitrate concentrations in the Northern Wadden Sea driven by freshwater discharge, decreasing riverine loads and denitrification. Helgoland Marine Research 62: 49-57.

von Storch, H. and F.W. Zwiers. 1999. Statistical analysis in climate research. Cambridge: Cambridge University Press.

Ward, J.R. and K.D. Lafferty. 2004. The elusive baseline of marine disease: Are diseases in ecosystems increasing? PLoS Biology 2: 542.

Weijerman, M., H. Lindeboom, and A.F. Zuur. 2005. Regime shifts in marine ecosystems of the North Sea and Wadden Sea. Marine Ecology Progress Series 298: 21-39.
Wichels, A., S. Biel, S. Gelderblom, H.R. Brinkhoff, T.H. Muyzer, and C. Schütt. 1998. Bacteriophage diversity in the North Sea. Applied and Environmental Microbiology 64: $4128-4133$.

Wiltshire, K.H. and C.-D. Dürselen. 2004. Revision and quality analyses of the Helgoland Reede long-term phytoplankton data archive. Helgoland Marine Research 58: 252-268.

Wiltshire, K.H., A.M. Malzahn, W. Greve, K. Wirtz, S. Janisch, P. Mangelsdorf, B. Manly, and M. Boersma. 2008. Resilience of North Sea phytoplankton spring bloom dynamics: An analysis of long-term data at Helgoland Roads. Limnology and Oceanography 53: 1294-1302.

Wiltshire, K.H. and B.F.J. Manly. 2004. The warming trend at Helgoland Roads, North Sea: Phytoplankton response. Helgoland Marine Research 58: 269-273. 